BYRON RANGIWAI

\title{
Walking backwards into the future: Prophecy as an approach for embedding Indigenous values in tertiary education
}

\section{Introduction}

Indigenous peoples understand time differently to Pākehā (Rangiwai, 2021a). Mahuika (2010) maintains that the notion of walking backwards into the future is a common one for Māori and other people of the Pacific. Roberts (2005) opines, "It is often said that Māori are a people who "walk backwards into the future," an aphorism that highlights the importance of seeking to understand the present and make informed decisions about the future through reference to the past" (p. 8).

Kame'eleihiwa (1992) and Trask (2000) opine that Hawaiians perceive the past as the time ahead and the future as the time behind. According to Kame'eleihiwa (1992), "[the] Hawaiian stands firmly in the present, with his back to the future, and his eyes fixed upon the past, seeking historical answers for present-day dilemmas" (pp. 22-23). 
Hau'ofa (2000) states that the past is considered the time in front for the peoples of the Pacific. Poignantly Māhina (2008) states that the past must "be placed in front of people as guidance in the present, and because the future has yet to happen, it must be placed to the back of or behind people in the present, where both past and future are symmetrically negotiated in the process" (p. 2).

With Māori and Pacific views of time in mind, this paper will argue that prophecy-predicting the future-may be used as an approach for embedding Indigenous values in tertiary education. This paper will use the example of Te Umutaoroa-a prophecy gifted by the nineteenth-century prophet Te Kooti Arikirangi Te Tūruki to Patuheuheu hapū in 1886to demonstrate how prophecy can be used to embed Indigenous values in tertiary education. Indeed, because we walk backwards into the future (Hau'ofa, 2000; Kame'eleihiwa, 1992; Māhina, 2008; Mahuika, 2010; Roberts, 2005; Trask, 2000), prophecy is the means through which we can conceptualise, theorise, visualise, and prepare for the future (Rangiwai, 2015).

\section{Prophecy}

Pākehā contact irrevocably impacted Māori (Rangiwai, 2015). Before our conversion to Christianity, we had our own Indigenous spirituality that mirrored our cultural and spiritual relationships with the environment (Rangiwai, 
2015). The consequences of Christianity on Māori are understood as being mainly negative. However, there are claims that engagement with Christianity resulted in some positive outcomes (Rangiwai, 2019b).

Before the New Zealand Wars (1845-1872), Māori political leadership was based on inherited authority (Rangiwai, 2015). However, the effects of Pākehā invasion and severe land loss changed Māori leadership style and function, which involved the appearance of new prophetic leaders (Winiata, 1967) in addition to traditional leaders (Rangiwai, 2015). The Māori prophets emerged from the periphery of mainstream Christianity and offered followers hope, identity and community, as part of an awe-inspiring response to colonisation and land loss (Rangiwai, 2015; Stenhouse \& Paterson, 2004).

The word prophet comes from the Greek prophêtēs (профіंтn), referring to one who speaks out or makes proclamations (Tishken, 2007). Prophets deal personally with supernatural forces (Tishken, 2007) and promote significant transformation within communities (Rangiwai, 2015). Prophets receive revelation from one or multiple divinities and communicate these to their followers (Humm, 2009).

While the terms prophet and prophecy are encumbered with Western and Judeo-Christian meaning, hypothetically, prophets and prophecy have always been part of Indigenous spirituality 
(Rangiwai, 2015). Indigenous prophets, therefore, endured in different forms and with different functions within their own Indigenous communities as prophetic guides, seers and spiritual mediators, who foresaw the events that would influence their people (Rangiwai, 2015).

The effect of both colonisation and introduced religions on Indigenous peoples rearranged the role of Indigenous prophets (Rangiwai, 2015). In a Māori context, new prophets arose, distinct from the traditional matakite and tohunga of the preChristian Māori world (Rangiwai, 2015). These new types of prophets inventively amalgamated new with old to resist colonisation (Rangiwai, 2015). The prophets created movements based on their political and spiritual revelations and encouraged their followers to maintain a sense of hope in the face of profound hardship (Rangiwai, 2015).

\section{Why prophecy?}

I have studied Māori prophecy since 2008. From my perspective, Māori Prophecy can inform a range of contexts. I have used Māori prophecy to study Māori land loss (Rangiwai, 2010a, 2010b, 2010c, 2011a, 2011b, 2011c), hapū development and transformation (Rangiwai, 2011d, 2011e, 2012a, 2012b, 2012c, 2012d, 2012e, 2012f, 2012g, 2013b, 2015, 2017d, 2018cc), and research methodology (Rangiwai, 2012g, 2012h, 2013a, 2015). Māori prophecy can inform resistance (Rangiwai, 2015, 
2017b) and Indigenous forms of critical theory (Rangiwai, 2015, 2017a). Māori prophecy has shaped Māori theology (Rangiwai, 2017c, 2018a, 2018b, 2018c, 2018d, 2018e, 20181, 2018m, 2018n, 2018s, 2018t, 2018z, 2019b, 2019d, forthcoming), and Māori theological approaches to the environment (Rangiwai, 2018o, 2018p).

My understanding of Māori prophecy has informed my research approach from 2008 to now (Rangiwai, 2018h, 2018j, 2018q, 2018r, 2018v, 2018w, 2018y, 2018dd. 2020d, 2021b; Rangiwai et al., 2021). I have used this approach to investigate a vast array of issues, including Bible translation and sexuality (Rangiwai, 2018g); perceptions of race in the media (Rangiwai, 2018f); leadership (Rangiwai, 2018k, 2018v, 2018w, 2018bb); tangihanga (Rangiwai, 2018aa), embalming, cremation, and the scattering of ashes (Rangiwai, 2018i, 2020b); theatre and sexuality (Rangiwai, 2018u), and religion (Rangiwai, 2018x); sexuality, culture and religion (Rangiwai, 2020c); sexuality and festivals (Rangiwai, 2019c); publishing (Rangiwai, 2019f); and academical dress (Rangiwai, 2019a, 2019e).

With this same approach, I have also explored COVID-19 (Enari \& Rangiwai, 2021; Rangiwai, 2020a, 2020d; Rangiwai \& Sciascia, 2021; Rangiwai et al., 2020b); digital teaching and learning (Rangiwai, 2020f; Rangiwai et al., 2020a, 2020b); academic supervision (Rangiwai, 2020e; Rangiwai et al., 2019); social media and education (Rangiwai, 
2020f); the history of Tama-ki-Hikurangi wharenui (Rangiwai, 2021e); my whānau history (Rangiwai, 2021b, 2021d, 2021e); digital marketing in tertiary education (Haurua \& Rangiwai, 2020); and digital innovation during COVID-19 (Enari \& Rangiwai, 2021).

\section{Te Kooti Arikirangi Te Turuki}

Te Kooti was a well-known nineteenth-century Māori prophet. In 1866 he was imprisoned on the Chatham Islands as a political prisoner with many others; here, he received religious revelations and conceived a plan to escape with his recently acquired followers (Binney, 1997). Te Kooti's revelations became the foundation for his Ringatū faith (Binney, 1997). My hapū, Patuheuheu, were followers of Te Kooti and built a wharenui, Tama-kiHikurangi, for him at Te Houhi (Rangiwai, 2021d). However, through the malevolent dealings of a Pākehā named Harry Burt, combined with the sinister manoeuvrings of the Crown, the people of Te Houhi-Patuheuheu, Ngāti Haka, Ngāti Manawa, and Ngāti Whare-were evicted at gunpoint (Rangiwai, 2015). Patuheuheu moved to Waiōhau (Rangiwai, 2015). As a result of this land loss, Te Kooti articulated a prophecy called Te Umutaoroathe slow-cooking earth oven-to give the people hope (Rangiwai, 2015). 


\section{The emergence of Te Umutaoroa - the slow cooking earth oven}

Te Umutaoroa is a prophetic, utopian discourse that promised Patuheuheu the return of their lost lands and resources (Binney, 2001). According to some narratives, this also includes discovering or generating other resources like diamonds, gold, oil, and minerals (Binney, 2001). The Reverend Hieke Tupe and Robert (Boy) Biddle claimed that Te Kooti had his vision in 1886 and named the land on which this event took place Te Umutaoroa (Binney, 2001). Tūhoe scholar Te Wharehuia Milroy corroborates the existence of Te Umutaoroa in the following way:

Te Umutaoroa was at Te Houhi; it was a place where Te Kooti visited and while he was at this place there was a lot of fog covering the area at that time. There, at that place, Te Kooti placed eight mauri: mauri atua, mauri whenua, mauri tangata, mauri whakapono, mauri whakaora i ngā iwi, mauri hōhonu, mauri arai atu i ngā pakanga, mauri whakahoki i ngā iwi. One of the statements that Te Kooti made was about Harry Burt finding only "rotting potatoes" at Te Umutaoroa; that the money he received in exchange for on-selling Te Houhi would be like "a pit of rotting potatoes". There was another prediction: "tao noa, tao noa, tērā ka tae mai te tamaiti māna e huki". This means that there is this umu still "operating" in its cooking state. Now whoever the tamaiti is, I don't know, but that person must appear to make Te Kooti's prediction 
come true; someone has to come out at some time or other, to prove Te Kooti's prediction right (Rangiwai, 2015, p. 145).

Within this umu pit, it is said that Te Kooti placed eight mauri stones to be uncovered by a future leader, his child or son, to restore all that the people of Te Houhi had lost (Binney, 2001). The Reverend Hieke Tupe gave the following meanings of the mauri of Te Umutaoroa:

te mauri atua: the essence of spirituality; the belief in God

te mauri whenua: the life force of the land te mauri tangata: the life force of the people te mauri whakapono: the power of belief, or faith te mauri whakaora i nga iwi: the power to heal the people

te mauri hohonu: the mauri [life force] of hidden wealth - minerals, gold, diamonds and oil (perhaps), which lie underground

te mauri arai atu i nga pakanga: the power to return war from this land to other countries te mauri whakahoki i nga iwi: the power to return people to their land (Binney, 2001, p. 158).

The revealing of these eight stones promises the people of Te Houhi spiritual and physical renewal, regeneration, reuniting of people and land, and economic security (Binney, 2001). To this day, though, Te Umutaoroa remains unfulfilled 
(Rangiwai, 2015). However, it is a narrative moulded for the various contexts within which it inspires and gives hope today as it did in the nineteenth century (Rangiwai, 2015).

\section{Te Umutaoroa model to embed Indigenous values in tertiary education}

As previously stated, walking backwards into the future is a Māori and Pacific approach to understanding time that acknowledges the past, engages with the present and forecasts the future. Conceptually, then, the notion of prophecy aligns with this understanding of time. Prophecy can be used to inform a range of diverse contexts, including, of course, tertiary education. This paper will use Te Kooti's Te Umutaoroa prophecy as an approach through which to demonstrate the embedding of Indigenous values in a tertiary education context. The following image is a model that incorporates the eight mauri featured in Te Kooti's prophecy. Indeed, this particular prophecy has a history of being re-interpreted in new and innovative ways (Binney, 2001; Rangiwai, 2021a). 


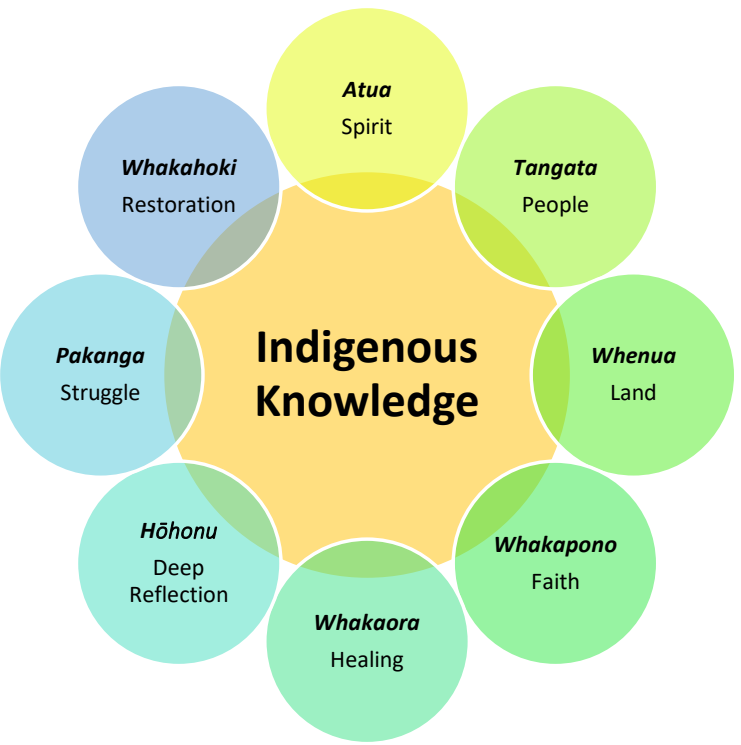

Figure 1. Te Umutaoroa model to embed Indigenous values in tertiary education

The following explains each part of the model and how it relates to embedding Indigenous values in tertiary education:

\section{Atua: Spirit}

In order to embed Indigenous values in tertiary education, the spiritual dimension must be acknowledged and negotiated through karakia (prayer) and other appropriate spiritual and cultural customs and protocols. Spirituality, of course, is an essential part of a Māori worldview (Mead, 2016). 
Tangata: People

In order to embed Indigenous values in tertiary education, whakapapa must be acknowledged and honoured. Managing relationships and demonstrating manaakitanga is an integral part of a Māori worldview (Mead, 2016).

\section{Whenua: Land}

In order to embed Indigenous values in tertiary education, the absolute centrality of land and belonging must be acknowledged and honoured. Whenua is both a word for land and placenta and therefore refers to Māori connections and emergence from Papatūānuku (Mead, 2016; Rangiwai, 2015).

\section{Whakapono: Faith}

Pono is a word that refers to honesty, integrity and faith. Therefore, in order to embed Indigenous values in tertiary education, trust is critical in relationships. Indeed, ensuring that relationships are maintained is a fundamental feature of a Māori worldview (Mead, 2016).

\section{Whakaora: Healing}

Whakaora is a word that refers to healing, salvation, and restoration. Thus, in order to embed Indigenous values in tertiary settings, education must be transformative and empowering as part of the decolonisation and healing process. 
Hōhonu: Deep reflection

In order to embed Indigenous values in tertiary education, students must be encouraged to deeply, critically, and esoterically reflect to find transformative solutions for themselves, their whānau, hapū, iwi, and community.

\section{Pakanga: Struggle}

Pakanga is a word that refers to battle or war. So, to embed Indigenous values in tertiary education, students must understand that for Māori and Indigenous peoples, education is a site of struggle, turmoil, and contradiction. It is necessary to push the boundaries and to interrupt the status quo to achieve transformation. As Smith (2012) argues, Indigenous peoples must reclaim space.

\section{Whakahoki: Restoration}

Whakahoki is a word that refers to returning and in the context of Te Kooti's prophecy, refers to restoring that which was taken away. Therefore, to embed Indigenous values in tertiary education, students must be encouraged to take their rightful places as Indigenous leaders in their whānau, hapū, iwi, and community. This can be achieved by empowering them to access knowledge and skills, and qualifications to make positive and lasting transformational change. 


\section{Conclusion}

For Māori the past is viewed as being 'in front', and that Māori traditions and narratives, rather than being stagnant, are active and cyclical, with the potential to be interpreted for contemporary contexts (Binney, 2001; Rangiwai, 2015). This paper has argued that Māori prophecy can be used as an approach to embed Indigenous values in tertiary education and Te Kooti's Te Umutaoroa prophecy provided a framework through which to realise the potential of prophecy in this regard. While this area requires further research, what is certain is that as we walk backwards into the future, just as our ancestors did, we may potentially reclaim, reconstruct, and restore knowledge and practices reframed in futuristic ways. 


\section{References}

Binney, J. (2001). Te Umutaoroa: The earth oven of long cooking. In A. Sharp \& P. McHugh (Eds.), Histories, power and loss: Uses of the past - a New Zealand commentary (pp. 146-64). Bridget Williams. Ka'ili, T. O. (2017). Marking indigeneity: The Tongan art of sociospatial relations. University of Arizona Press. Kame'eleihiwa, L. (1992). Native land and foreign desires: Pehea lā e pono ai? Bishop Museum Press.

Enari, D. \& Rangiwai, B. W. (2021). Digital innovation and funeral practices: Māori and Samoan perspectives during the COVID-19 pandemic. AlterNative: An International Journal of Indigenous Peoples, $1-6$. https://doi.org/10.1177/11771801211015568

Hau'ofa, E. (2000). Epilogue: Pasts to remember. In R. Borofsky (Ed.), Remembrance of Pacific pasts: An invitation to remake history (pp. 453-471). University of Hawai'i Press.

Haurua, J., \& Rangiwai, B. (2020). Digital marketing in Māori higher education: A case study of $\mathrm{Te}$ Wānanga o Aotearoa. Te Kaharoa: The eJournal on Indigenous Pacific Issues, 15(1), 1-21. https://www.tekaharoa.com/index.php/tekaharoa $\angle$ article/view/302

Humm, A. (2009). Psychology of prophecy in early Christianity: Prophetism and religious altered states of consciousness. Gorgias Press.

Māhina, 'O. (2008). From vale, ignorance, to 'ilo, knowledge, to poto, skill, the Tongan theory of ako, 
education: Theorizing old problems anew. AlterNative: An International Journal of Indigenous Scholarship, 4(1), 67-96.

Mahuika, N. (2010). Kōrero tuku iho: Reconfiguring oral history and oral tradition (Unpublished doctoral thesis, University of Waikato). https://researchcommons.waikato.ac.nz/handle/1 $\underline{0289 / 6293}$

Mead, H. M. (2016). Tikanga Māori. Huia.

Rangiwai, B. (2010a). The effects of racism on Māori land loss: Colonising discourses for Patuheuheu and Ngāti Haka [Unpublished master's thesis, Te Whare Wānanga o Awanuiārangi].

Rangiwai, B. (2010b, April). Race, difference and identity: The effects of nineteenth-century racial discourse on Māori land loss. Presentation at Te Whare Wānanga o Awanuiārangi, Whakatāne, New Zealand.

Rangiwai, B. (2010c, August). My research journey: The effects of racism on Māori land loss. Presentation at the Māori and Pasifika Postgraduate Students Wānanga Series, Ngā Wai o Horotiu Marae, Auckland University of Technology, Auckland, New Zealand.

Rangiwai, B. (2011a, October). From prophecy to praxis: A critical analysis of Patuheuheu land loss, prophecy and hapū praxis. Presentation at Ngā Wai o Horotiu Marae, Auckland University of Technology, Auckland, New Zealand. 
Rangiwai, B. (2011b, November). From prophecy to praxis: A critical analysis of Patuheuheu land loss, prophecy and hapu praxis. Presentation at the Māori and Pasifika Postgraduate Students Symposium, Awataha Marae, Auckland, New Zealand.

Rangiwai, B. (2011c). 'Race' and the politics of land loss: Colonising discourses for

Patuheuheu and Ngāti Haka. Te Kaharoa: The eJournal of Indigenous Pacific Issues, 4 (1), 40-96. https://www.tekaharoa.com/index.php/tekaharoa /article/view/112

Rangiwai, B. (2011d). Te Umutaoroa, Patuheuheu and Ngāti Haka: Towards a

prophetic model for unity and transformation. Te Kaharoa: The eJournal of Indigenous Pacific Issues, 4 $1-32$.

https://www.tekaharoa.com/index.php/tekaharoa /article/view/110

Rangiwai, B. (2011e, July). Towards a model for research and community development. Presentation at University of the South Pacific, Rarotonga Campus, Rarotonga, Cook Islands.

Rangiwai, B. (2012a, November). Te Kooti Arikirangi Te Turuki and Te Umutaoroa: From prophecy to decolonisation and praxis. Paper presented to the Tapuika iwi community at the Māori and Pasifika Postgraduate Students Wānanga Series Symposium, 23-29 November, Moko Marae, Waitangi, Te Puke, New Zealand. 
Rangiwai, B. (2012b, May). Nineteenth-century prophetic resistance: The case of Te Kooti and the 'Waiohau Fraud'. Paper presented at 'Assembly', St Paul Street Gallery, Auckland University of Technology, Auckland, New Zealand.

Rangiwai, B. (2012c). The potential of prophecy: Māori prophetism and community development. Te Kaharoa: The eJournal of Indigenous Pacific Issues, 1(1), Special Edition 1, 69-85. https://www.tekaharoa.com/index.php/tekaharoa /article/view/96

Rangiwai, B. (2012d, June). The potential of prophecy: Mãori prophetism and community development. Paper presented at the International Indigenous Development Research Conference, University of Auckland, Auckland, New Zealand.

Rangiwai, B. (2012e, May). Prophecy and praxis: Mãori prophetic movements and community development. Presentation at the Māori and Pasifika Postgraduate Students Wānanga Series, Ngā Wai o Horotiu Marae, Auckland University of Technology, Auckland, New Zealand.

Rangiwai, B. (2012f, June). Prophecy and praxis: Māori prophetic movements and community praxis. Paper presented at the Native American and Indigenous Studies Conference, Mohegan Indian Reservation, Uncasville, CT.

Rangiwai, B. (2012g, October). Prophecy and praxis: The Te Umutaoroa (earth oven of long cooking) research model and community development. Paper 
presented at He Wānanga: Māori leadership in literacy and numeracy, Waiariki Institute of Technology, Rotorua, New Zealand.

Rangiwai, B. (2012h, April). The Te Umutaoroa (earth oven of long cooking) research model. Presentation at University of the South Pacific, Rarotonga Campus, Rarotonga, Cook Islands.

Rangiwai, B. (2013a, September). Ngā mauri e waru: The development of the Te Umutaoroa (slow cooking earth oven) research model. Presentation at University of the South Pacific, Rarotonga Campus, Rarotonga, Cook Islands.

Rangiwai, B. (2013b, November). From the Rangihau model to the Te Umutaoroa hapū development model. Paper presented to the Tapuika iwi community at the Māori and Pasifika Postgraduate Students Wānanga Series Symposium, November, Moko Marae, Waitangi, Te Puke, New Zealand.

Rangiwai, B. (2015). Ko au ko Te Umutaoroa, ko Te Umutaoroa ko au: Toward a Patuheuheu hapū development model [Unpublished doctoral thesis, Auckland University of Technology]. https://openrepository.aut.ac.nz/handle/10292/8 851

Rangiwai, B. (2017a). The critical theory of Te Kooti Arikirangi Te Turuki. Te Kaharoa: The eJournal on Indigenous Pacific Issues, 10(1), 194240. https://www.tekaharoa.com/index.php/teka haroa/article/view/165 
Rangiwai, B. (2017b). Māori prophetic movements as sites of political resistance: A case study. Te Kaharoa: The eJournal on Indigenous Pacific Issues, 10(1),

192. https://www.tekaharoa.com/index.php/teka haroa/article/view/160

Rangiwai, B. (2017c, November). Syncretism in Māori theology. Paper presented at MAI Doctoral Conference, November 16-18, Palmerston North.

Rangiwai, B. (2017d). Te Umutaoroa - the slowcooking earth oven: A case study of intergenerational transference. Te Kaharoa: The eJournal on Indigenous Pacific Issues, 10(1), 241275. https://www.tekaharoa.com/index.php/teka haroa/article/view/168

Rangiwai, B. (2018a). Atuatanga. Te Kaharoa: The eJournal on Indigenous Pacific Issues, 11(1), 222224.

https://www.tekaharoa.com/index.php/tekaharoa Larticle/view/209

Rangiwai, B. (2018b). The Atuatanga model: A methodology for researching Māori theology. Te Kaharoa: The eJournal on Indigenous Pacific Issues, 11(1), 181- 194. https://www.tekaharoa.com/index.php/tekaharoa /article/view/191/164

Rangiwai, B. (2018c, November). Atuatanga, syncretism, and contextual theology: A view of Māori theology. Paper presented at International 
Indigenous Research Conference, University of Auckland, Auckland, New Zealand.

Rangiwai, B. (2018d). Atuatanga and syncretism: A view of Māori theology. Te Kaharoa: The eJournal on Indigenous Pacific Issues, 11(1), 653-661. https://www.tekaharoa.com/index.php/tekaharoa /article/view/242

Rangiwai, B. (2018e). "God is..." : A personal theology based on stories from my grandmother. Te Kaharoa: The eJournal on Indigenous Pacific Issues, 11(1), 171-172.

https://www.tekaharoa.com/index.php/tekaharoa /article/view/179/159

Rangiwai, B. (2018f). Hana Kōkō: What's wrong with Nelson's Māori Santa? Te Kaharoa: The eJournal on Indigenous Pacific Issues, 11(1), 676-684. https://www.tekaharoa.com/index.php/tekaharoa /article/view/244

Rangiwai, B. (2018g). "Hell... unless they repent of their sins and turn to God": The problem of Bible translation and the potential impacts of Israel Folau's comments on Māori and Pasifika minority sexualities. Te Kaharoa: The eJournal on Indigenous Pacific Issues, 11(1), 250-282. https://www.tekaharoa.com/index.php/tekaharoa Larticle/view/214

Rangiwai, B. (2018h). Hereditary entanglement whakapapa and genealogical locatedness in Māori research: A researcher's personal experience. Te Kaharoa: The eJournal on Indigenous Pacific Issues, 
$11(1)$, 139-170.

https://www.tekaharoa.com/index.php/tekaharoa /article/view/177/158

Rangiwai, B. (2018i). The impacts of contemporary embalming practices on tikanga Māori. Te Kaharoa: The eJournal on Indigenous Pacific Issues, 11(1), 229-249.

https://www.tekaharoa.com/index.php/tekaharoa $\angle$ article/view/213

Rangiwai, B. (2018j, March). Inspiring, innovating and realising (k)new knowledge through rangahau. Paper presented at Ko Manawatina, Ko Manawatoka Rangahau Workshop, Te Ihu Takiwā, Manukau Campus, Te Wānanga o Aotearoa, Māngere, Auckland.

Rangiwai, B. (2018k). Ka mua, ka muri: A new transformative leadership theory based on a prophecy by Te Kooti Arikirangi Te Turuki. Te Kaharoa: The eJournal on Indigenous Pacific Issues, 11(1), 604-637. https://www.tekaharoa.com/index.php/tekaharoa /article/view/239

Rangiwai, B. (20181). Karaititanga: Some reflections on my Christology. Te Kaharoa: The eJournal on Indigenous Pacific Issues, 11(1), 591-603. https://www.tekaharoa.com/index.php/tekaharoa /article/view/238

Rangiwai, B. (2018m, September 12). Karaititanga: Reflections on my Christology Part One [Web log post]. 
https://indigenousknowledgenetwork.net/2018/0 9/12/karaititanga-reflections-on-my-christologypart-1/

Rangiwai, B. (2018n, September 17). Karaititanga: Reflections on my Christology Part Two [Web log post].

https://indigenousknowledgenetwork.net/2018/0 9/17/karaititanga-reflections-on-my-christologypart-2/

Rangiwai, B. (2018o). Ko au ko te taiao, ko te taio ko au - I am the environment and the environment is me: A Māori theology of the environment. Te Kaharoa: The eJournal on Indigenous Pacific Issues, 11(1), 638-652. https://www.tekaharoa.com/index.php/tekaharoa /article/view/241

Rangiwai, B. (2018p, November). Ko au ko te taiao, ko te taiao ko au: I am the environment and the environment is me: A Mãori theology of the environment. Keynote address presented at Sea of Faith Conference, Wellington.

Rangiwai, B. (2018q, July). Mãori prophetic leadership: Ka mua, ka muri - walking backwards into the future. Paper presented at Leadership Pacific Inaugural Conference, University of the South Pacific, Suva, Fiji.

Rangiwai, B. (2018r, July). Mãori prophetic leadership: Ka mua, ka muri - walking backwards into the future. Paper presented at He Waka Hiringa: Master 
of Applied Indigenous Knowledge Session, Te Wānanga o Aotearoa, Māngere, Auckland.

Rangiwai, B. (2018s). Mixed-up theology. Te Kaharoa: The eJournal on Indigenous Pacific Issues, 11(1), 175-176.

https://www.tekaharoa.com/index.php/tekaharoa /article/view/184

Rangiwai, B. (2018t). My emerging theology. Te Kaharoa: The eJournal on Indigenous Pacific Issues, 11(1), $337-$ 365. https://www.tekaharoa.com/index.php/teka haroa/article/view/231

Rangiwai, B. (2018u). A reflection on Priscilla Queen of the Desert. Te Kaharoa: The eJournal on Indigenous Pacific Issues, 11(1), 493-497. https://www.tekaharoa.com/index.php/tekaharoa Larticle/view/230

Rangiwai, B. (2018v). Rangahau and transformative leadership. Te Kaharoa: The eJournal on Indigenous Pacific Issues, 11(1), 662-675. https://www.tekaharoa.com/index.php/tekaharoa /article/view/243

Rangiwai, B. (2018w, November). Rangahau and transformative leadership. Keynote address presented the Bicultural Social Work Conference, Te Wānanga o Aotearoa, Auckland.

Rangiwai, B. (2018x). Reflections on The Book of Mormon musical: Flirtations with Mormon theology. Te Kaharoa: The eJournal on Indigenous Pacific Issues, 11(1), 283-318. Retrieved: 
https://www.tekaharoa.com/index.php/tekaharoa $\angle$ article/view/215

Rangiwai, B. (2018y). "Stories are knowledge, and knowledge is literature": Viewing and re-viewing sites/cites of mātauranga Māori as an alternative to traditional Western literature reviews. Te Kaharoa: The eJournal on Indigenous Pacific Issues, 11(1), 489-492.

https://www.tekaharoa.com/index.php/tekaharoa /article/view/229

Rangiwai, B. (2018z). Syncretism in Māori theology. Te Kaharoa: The eJournal on Indigenous Pacific Issues, 11(1), 177-180.

https://www.tekaharoa.com/index.php/tekaharoa Larticle/view/186/162

Rangiwai, B. (2018aa). Tangihanga. Te Kaharoa: The eJournal on Indigenous Pacific Issues, 11(1), 173174.

https://www.tekaharoa.com/index.php/tekaharoa /article/view/182/160

Rangiwai, B. (2018bb). Te Kooti's slow-cooking earth oven prophecy: A Patuheuheu account and a new transformative leadership theory. Te Kaharoa: The eJournal on Indigenous Pacific Issues, 11(1), 1-119. https://www.tekaharoa.com/index.php/tekaharoa $\angle$ article / view $/ 240$

Rangiwai, B. (2018cc). Te Umutaoroa: A model for Patuheuheu hapū development. Te Kaharoa: The eJournal on Indigenous Pacific Issues, 11(1), 21-100. 
https://www.tekaharoa.com/index.php/tekaharoa /article/view/176

Rangiwai, B. (2018dd). Te Umutaoroa: A Patuheuheu research model. Te Kaharoa: The eJournal on Indigenous Pacific Issues, 11(1), 1-20. https://www.tekaharoa.com/index.php/tekaharoa /article/view/169/153

Rangiwai, B. (2019a). Kākahu and gown: The incorporation of kākahu into academical dress in Aotearoa New Zealand with an example of a kākahu worn by a City University of New York graduation ceremony in 2006 - an interview with Sarah Smith. Te Kaharoa: The eJournal on Indigenous Pacific Issues, 12(1), 1-27. https://www.tekaharoa.com/index.php/tekaharoa /article/view/246

Rangiwai, B. (2019b). A Kaupapa Māori study of the positive impacts of syncretism on the development of Christian faith among Māori from my faith-world perspective [Unpublished doctoral thesis, University of

Otago].

https://ourarchive.otago.ac.nz/handle/10523/984 $\underline{7}$

Rangiwai, B. (2019c). The spectacle of the queer "Other": Māori gay(zing) at the $41^{\text {st }}$ Sydney Gay and Lesbian Mardi Gras 2019. Te Kaharoa: The eJournal on Indigenous Pacific Issues, 12(1), 1-13. https://www.tekaharoa.com/index.php/tekaharoa Larticle/view/267 
Rangiwai, B. (2019d). My syncretistic faith-world perspective. Te Kaharoa: The eJournal on Indigenous Pacific Issues, 12(1), 1-92. https://www.tekaharoa.com/index.php/tekaharoa /article/view/279

Rangiwai, B. (2019e). Wānanga habits: The academical dress of Te Wānanga o Aotearoa - notes and images. Te Kaharoa: The eJournal on Indigenous Pacific Issues, 12(1), 1-20. https://www.tekaharoa.com/index.php/tekaharoa Larticle/view/268

Rangiwai, B. (2019f). "Write(Right) the World": The benefits of publishing in Te Kaharoa: The eJournal on Indigenous Pacific Issues for Master of Applied Indigenous Knowledge students, 2018-2019. Te Kaharoa: The eJournal on Indigenous Pacific Issues, 12(1), 1-33.

Rangiwai, B. (2020a). The impacts of COVID-19 on hongi and the advent of the 'East Coast Wave'. In Te Kaharoa: The eJournal on Indigenous Pacific Issues, 15(1), $1-14$. https://www.tekaharoa.com/index.php/tekaharoa Larticle/view/289

Rangiwai, B. (2020b). The impacts on tikanga of the Hindu practice of scattering human ashes into waterways compared with the practice of disposing of blood via the wastewater system as part of the arterial embalming process. Te Kaharoa: The eJournal on Indigenous Pacific Issues, 15(1), 1-24. 
https://www.tekaharoa.com/index.php/tekaharoa /article/view $/ 288$

Rangiwai, B. (2020c). "My heart goes shut up, shut up!": Gay marriage to an Indian man-one year on. Te Kaharoa: The eJournal on Indigenous Pacific Issues, 15(1), 1-16. https://www.tekaharoa.com/index.php/tekaharoa /article/view/286

Rangiwai, B. (2020d). The potential effects of COVID19 on research interviews in Year 2 of the Master of Applied Indigenous Knowledge programme at $\mathrm{Te}$ Wānanga o Aotearoa in Māngere.

Te Kaharoa: The eJournal on Indigenous Pacific Issues, 15(1), $1-13$. https://www.tekaharoa.com/index.php/tekaharoa /article/view/306

Rangiwai, B. (2020e). Supervision in the Master of Applied Indigenous Knowledge programme at $\mathrm{Te}$ Wānanga o Aotearoa in Māngere. Te Kaharoa: The eJournal on Indigenous Pacific Issues, 15(1), 1-11. https://doi.org/10.24135/tekaharoa.v15i1.307

Rangiwai, B. (2020f). Facebook as a substitute for kanohi ki te kanohi in the Master of Applied Indigenous Knowledge programme at Te Wānanga o Aotearoa in Māngere. Te Kaharoa: The eJournal on Indigenous Pacific Issues, 15(1), 1-17. https://www.tekaharoa.com/index.php/tekaharoa /article/view/309 
Rangiwai, B. (forthcoming). Māori theology and syncretism. AlterNative: An International Journal of Indigenous Peoples.

Rangiwai, B. (2021a). Back to the future: Using prophecy to support Māori student success in tertiary education. Te Kaharoa: The eJournal on Indigenous Pacific Issues, 17(1), 1-29. https://www.tekaharoa.com/index.php/tekaharoa /article/view/356

Rangiwai, B. (2021b). Edward Fitzgerald-pioneer, coach driver, shepherd, and rabitter: A very brief reflection. Te Kaharoa: The eJournal on Indigenous Pacific Issues, 17(1), 1-11. https://www.tekaharoa.com/index.php/tekaharoa /article/view/338

Rangiwai, B. (2021c). It's about me! My approach to autoethnography. Te Kaharoa: The eJournal on Indigenous Pacific Issues, 17(1), 1-15. https://www.tekaharoa.com/index.php/tekaharoa Larticle/view/355

Rangiwai, B. (2021d). Nan's stories. Te Kaharoa: The eJournal on Indigenous Pacific Issues, 17(1), 1-22. https://doi.org/10.24135/tekaharoa.v17i1.347

Rangiwai, B. (2021e). Tama-ki-Hikurangi: A whare built for Te Kooti. Te Kaharoa: The eJournal on Indigenous Pacific Issues, 17(1), 1-25. https://www.tekaharoa.com/index.php/tekaharoa /article/view/340

Rangiwai, B., Albert, M., Bell, T., Cuthers, W., Filisi, F., Hotereni, V., Lambert, C., Leuluai, R., Sasa- 
Tepania, L., Walker, D. \& Yor, A. (2019). He Raranga Tangata: An Māori and Indigenous master's research supervision model derived from our experiences of the Master of Applied Indigenous Knowledge programme at Te Wānanga o Aotearoa in Māngere. Te Kaharoa: The eJournal on Indigenous Pacific Issues, 12(1), 1-13. https://www.tekaharoa.com/index.php/tekaharoa /article/view/283

Rangiwai, B., Enari, D., Masae, C., Paea, D., TahilanuMapili, L. \& Vailahi, V. (2021). Lost in translation: Reflexive thematic analysis in research with Pacific peoples. Te Kaharoa: The eJournal on Indigenous Pacific Issues, 17(1). https://www.tekaharoa.com/index.php/tekaharoa /article/view/354

Rangiwai, B. W. \& Sciascia, A. D. (2021). The impacts of COVID-19 on tangihanga. Journal of Global Indigeneity, 5(1), 1-14. https://www.journalofglobalindigeneity.com/articl e/19435-the-impacts-of-covid-19-on-tangihanga

Rangiwai, B., Simati-Kumar, B. \& Mataroa, R. (2020a). The He Waka Hiringa Map 2020-2021: Using He Raranga Tangata to support the implementation of the He Waka Hiringa Map in the Master of Applied Indigenous Knowledge programme at Te Wānanga o Aotearoa in Māngere. Te Kaharoa: The eJournal on Indigenous Pacific Issues, 15(1), 1-12. https://www.tekaharoa.com/index.php/tekaharoa /article/view/294 
Rangiwai, Simati-Kumar, B., Mataroa, R. (2020b). The impacts of COVID-19 on the 2020 cohort of the Master of Applied Indigenous Knowledge programme at Te Wānanga o Aotearoa in Māngere. Te Kaharoa: The eJournal on Indigenous Pacific Issues, 15(1), $1-21$. https://www.tekaharoa.com/index.php/tekaharoa /article/view/301

Roberts, R. M. (2005). Walking backwards into the future: Māori views on genetically modified organisms. Perspectives on Indigenous Knowledge, WINHEC Journal.

http://www.winhec.org/docs/pdfs/Journal/Mere\%20Roberts.pdf Smith, L. T. (2012). Decolonizing methodologies: Research and Indigenous peoples. Zed Books. Stenhouse, J. \& Paterson, L. (2004). Ngā poropiti me ngā hāhi - Prophets and the churches. In T. M. Ka'ai, J. C. Moorfield, M. P. J. Reilly, \& S. Mosley, Ki te whaiao: An introduction to Māori culture and society (pp.171-180). Pearson.

Tishken, J. E. (2007). The history of prophecy in West Africa: Indigenous, Islamic, and Christian. History Compass, 5(5), 1468-1482.

Trask, H-K. (2000). Natives and anthropologists: The colonial struggle. In D. Hanlon \& G. M. White (Eds.), Voyaging through the contemporary Pacific (pp. 255263). Rowman \& Littlefield.

Winiata, M. (1967). The changing role of the leader in Maori society: A study in social change and race relations. Blackwood. 